\title{
Chełmno i Toruń. Początki miast na ziemi chełmińskiej
}

\section{Chelmno and Toruń. The origins of towns in Chelmno Land}

Zarys treści. Podsumowanie wiedzy i badań nad początkami Chełmna i Torunia z uwzględnieniem opracowań historycznych oraz najnowszych wyników badań archeologicznych. Omówienie warunków powstania tych ośrodków, czynników kształtowania sieci osadniczej w najbliższym otoczeniu, podkreślenie rangi tradycji miejsca. Wskazanie różnic i podobieństw w funkcjonowaniu Chełmna i Torunia - ważnych elementów struktur osadniczych oraz punktów węzłowych połączeń komunikacyjnych we wczesnym średniowieczu.

Slowa kluczowe: wczesne średniowiecze, ziemia chełmińska, przywilej lokacyjny, geneza ośrodków miejskich, stan badań.

W studiach nad dziejami urbanizacji ziemi chełmińskiej, jak również całych Prus, szczególne znaczenie ma dokument lokacyjny wystawiony 28 grudnia 1233 roku przez wielkiego mistrza Niemieckiego Zakonu Szpitalnego św. Marii w Jerozolimie Hermana von Salza i mistrza krajowego Hermana Balka. W jednym przywileju określone zostały bowiem ramy prawno-ustrojowe dla Chełmna i Torunia, dwóch pierwszych i największych miast lokowanych na ziemi chełmińskiej. Był to dokument sporządzony w oparciu o wzorce zachodnioeuropejskie, szczególnie magdeburskie i flamandzkie, w wielu elementach postępowy i nowatorski, wprowadzający nową jakość życia społeczno-gospodarczego na tym obszarze (Zielińska-Melkowska 1986). Posiadał on wyjątkową wagę, nie tylko dlatego, że stanowił przywilej dla miast lokowanych przez Zakon na świeżo pozyskanym przez nich terenie, ale dlatego, że na lata, jako tzw. prawo chełmińskie, stał się punktem odniesienia dla lokacji ponad 200 innych ośrodków położonych w granicach państwa zakonnego i poza nim (Biskup, Labuda 1986, s. 175). 
W niniejszym artykule będzie nas interesować przede wszystkim, budząca wiele kontrowersji w środkowoeuropejskiej, zwłaszcza polskiej historiografii, kwestia kontynuacji osadniczej i nawiązania miast nowo lokowanych do przedlokacyjnych form osadniczych o tradycjach wczesnośredniowiecznych. Pytanie jakie stawiamy to: czy decyzje o lokalizacji, podjęte przez zakon krzyżacki w kilka lat po przybyciu na pogranicze kujawsko-chełmińskie, uwzględniały zarówno w przypadku Chełmna, jak i Torunia podobne uwarunkowania społeczno-gospodarcze, demograficzne i osadnicze, czy też mamy do czynienia z różnymi modelami kreacji omawianych ośrodków miejskich? Czy podstawą lokacji była w obu przypadkach jakaś wcześniejsza struktura osadnicza, czy też istniały między nimi zasadnicze różnice pod tym względem? Problem ten nieraz zajmował badaczy, zarówno historyków, jak i archeologów, próbujących wyjaśnić kwestie dość skomplikowanych dziejów lokacji Chełmna i Torunia, zazwyczaj traktowanych osobno. W przypadku Torunia należy tu wymienić zwłaszcza publikacje Jana Powierskiego (1968; 1971; 1977), Tomasza Jasińskiego (1981; 1999) oraz Jadwigi Chudziakowej $(1973 ; 1976 ; 1994 ; 1999)$. Natomiast w odniesieniu do początków Chełmna prace Zenona Huberta Nowaka (1987)1, Andrzeja Koli (1975), Sławomira Jóźwiaka (1996) i Romana Czai (2006). Wspólny dokument wystawiony dla obu miast upoważnia nas jednak do analizy porównawczej Chełmna i Torunia pod kątem ich wczesnośredniowiecznych „poprzedników”. Poglądy jakie sformułowano na ten temat trudno uznać za jednomyślne, nie ma jednak potrzeby szczegółowego referowania ich w tym miejscu. Najczęściej główna oś dyskusji naukowej skupiała się na kwestii ich kolejnych translokacji i potencjalnego istnienia w obu przypadkach proto- czy też wczesnomiejskich ośrodków osadniczych. Dość wyraziście i z wykorzystaniem dostępnej bazy źródłowej temat ten od strony historycznej zaprezentował swego czasu T. Jasiński, próbując skonfrontować poglądy na kwestie genezy Chełmna i Torunia w świetle wspólnego aktu lokacyjnego z roku 1233 i jego odnowionej wersji z roku 1251 (Jasiński 1980; 1982).

Przyjrzyjmy się zatem obu miastom z punktu widzenia ich przedlokacyjnego etapu rozwoju, wykorzystując w tym celu przede wszystkim wyniki dotychczasowych badań archeologicznych. Musimy jednak pamiętać o istnieniu wyraźnych dysproporcji pomiędzy stanem i poziomem badań nad genezą opisywanych ośrodków; badania przedlokacyjnego Torunia wciąż pozostają dalekie od zadowalających ${ }^{2}$. W pierwszej kolejności spróbujmy zatem przyjrzeć się początkom Chełmna.

${ }^{1}$ Pierwsze wydanie monografii poświęconej Chełmnu pod tym samym tytułem i opracowane przez tych samych autorów ukazało się w 1968 roku.

${ }^{2}$ Mimo prowadzonych od wielu już lat badań archeologicznych o różnym stopniu zaawansowania, obejmujących zarówno Stare Miasto, jak i przedmieścia Torunia, wciąż niewiele możemy powiedzieć o początkach zabudowy miasta, jej rozwoju, zasięgu przestrzennym. Jeszcze mniej w świetle posiadanych informacji wiemy o okresie poprzedzającym krzyżacką lokację miasta. Nawarstwienia 


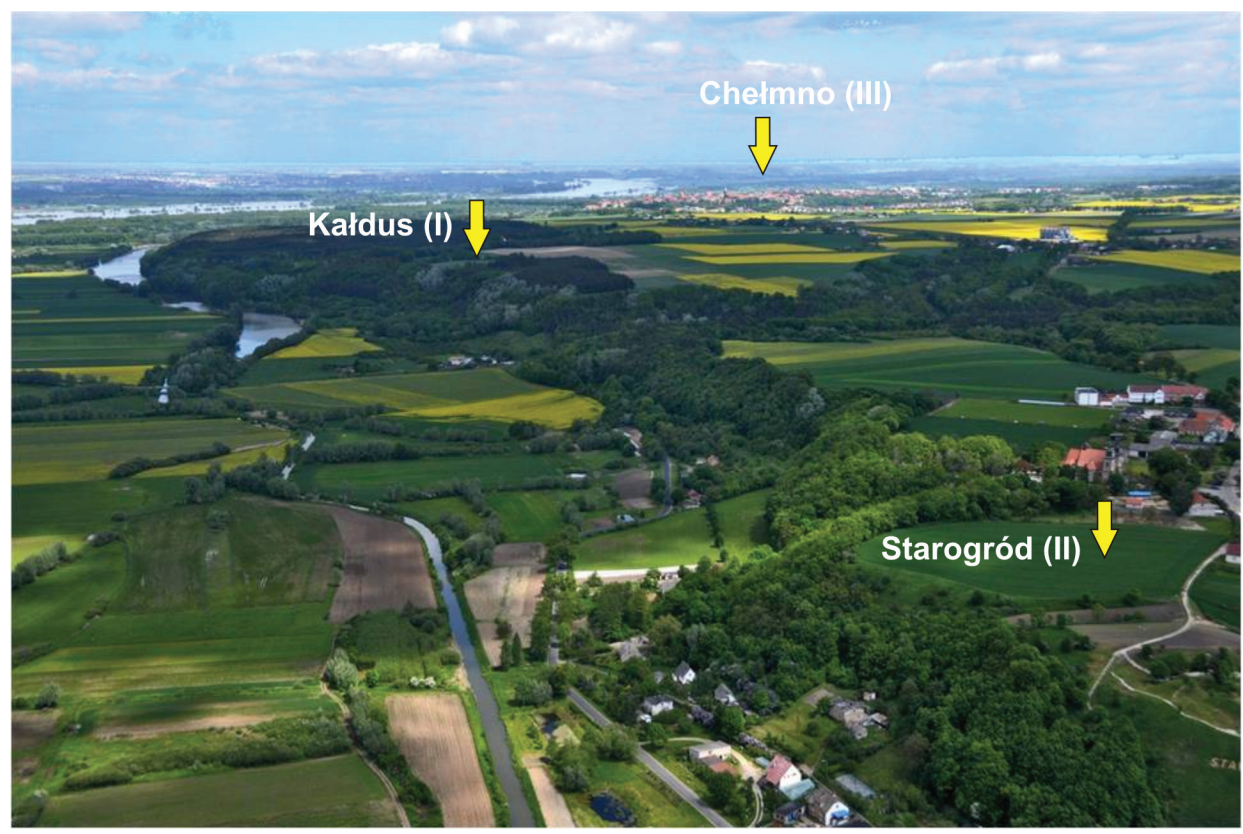

Ryc. 1. Widok na Chełmno, Kałdus i Starogród; kolejne etapy translokacji miasta (fot. W. Stępień)

Fig. 1. View of Chełmno, Kałdus and Starogród; the successive stages of the town translocation (photo W. Stępień)

Pierwotne Chełmno, wzmiankowane w falsyfikacie mogileńskim w 1065/1147 roku ${ }^{3}$, przekazane Krzyżakom przez Konrada Mazowieckiego w 1228 roku, znajdowało się przy dzisiejszej Górze św. Wawrzyńca w Kałdusie (ryc. 1). Etymologia nazwy miasta nie budzi wątpliwości, gdyż wiąże się ją powszechnie ze staropolskim wyrazem Chełm - wzgórze (łac. Culmen). Na podstawie dotychczasowych badań archeologicznych stwierdzono, że w 2. połowie XII i w początkach 1. ćwierci XIII wieku był to rozległy kompleks osadniczy o powierzchni kilkunastu hektarów (ryc. 2), obejmujący teren dwuczłonowego grodu położonego na północ od Góry św. Wawrzyńca i osadę podgrodową o charakterze rzemieślniczo-handlowym z karczmą, targiem i rozległym cmentarzem (Chudziak 1998; 2003a). Nekropolię

identyfikowane z osadnictwem przedlokacyjnym (przedkrzyżackim) odkryte zostały wyłącznie w strefie wzgórza zamkowego oraz punktowo w okolicach ulicy Pod Krzywą Wieżą (badania L. Grzeszkiewicz-Kotlewskiej w 2005 roku; niestety, odkrycie to nie zostało zweryfikowane). Charakter hipotetyczny mają również stwierdzenia odnoszące się do datowania na okres wczesnośredniowieczny warstwy odkrytej przy Ratuszu Staromiejskim (Chudziakowa 1999, s. 79). Potwierdzenia wymagają ponadto ustalenia chronologii stanowisk odkrytych na terenie Torunia, uznawanych za wczesnośredniowieczne (XI-XII wiek?) (Chudziakowa 1999, s. 71).

${ }^{3} \mathrm{Z}$ dokumentu tego dowiadujemy się o istnieniu w Chełmnie targu i karczmy: In Culmine nonum forum et tabernario (CDM, nr 22). Jest to jednocześnie pierwsza wzmianka o tym ośrodku osadniczym. 
należy uznać za najstarszą i największą na ziemi chełmińskiej (w sumie ponad 1500 grobów); założono ją zapewne na przełomie X i XI wieku, a użytkowano jeszcze w 1. ćwierci XIII stulecia (Chudziak 2006a, s. 157 i nn.; Chudziak, Bojarski, Stawska 2010, s. 105 i nn.), o czym świadczą monety występujące w grobach, między innymi brakteat Angelus przypisywany mennictwu Henryka Brodatego, czy monety księżnej Heleny znojemskiej (ryc. 3) (Musiałowski 2006, s. 105; 2010, s. 141). Opisywany ośrodek położony był na skrzyżowaniu głównych szlaków dalekosiężnych przechodzących przez ziemię chełmińską, szlaku wiślanego oraz lądowego prowadzącego w kierunku Rusi, co potwierdzają liczne importy. Poszczególne funkcje przedlokacyjnego Chełmna, charakterystyczne dla ośrodków o profilu wczesnomiejskim, odzwierciedlają z jednej strony pozostałości zabudowy (zwarty układ budynków mieszkalnych o konstrukcji zrębowej odkryty na grodzisku), duży budynek o konstrukcji sumikowo-łątkowej na osadzie podgrodowej (domniemana karczma) oraz liczne jamy mieszkalno-gospodarcze i produkcyjne, z drugiej zaś różnego rodzaju przedmioty, takie jak oporządzenie jeździeckie i broń, utensylia kupieckie, zwłaszcza wagi i odważniki, liczne monety, w sumie ponad 200 znanych egzemplarzy, narzędzia i odpady związane z działalnością metalurgiczną, w tym złotniczą, ponadto dewocjonalia chrześcijańskie, przedmioty do gry itp. (ryc. 4) (Chudziak 2003b; 2006b). Gród z rozległym zapleczem stanowił centrum kasztelani zajmującej zachodnią część międzyrzecza Wisły, Drwęcy i Osy (ryc. 5). Jej zasięg odtworzył przekonywująco J. Powierski na podstawie analizy klucza własnościowego wojewody Żyry (Powierski 1973, s. 9; por. też Bieniak 1970, s. 33 i nn.), co dokładnie odpowiada zasięgowi struktur mezoregionalnych określonych na podstawie wyników analizy osadniczej źródeł archeologicznych (Chudziak 1996, s. 196-198). Kasztelania stanowiła zasadniczy trzon obszaru określonego w źródłach krzyżackich jako ziemia chełmińska (łac. terra culmensis). Szczególną rangę Chełmna widać również w zagęszczeniu lokalnego osadnictwa datowanego na XII i 1. połowę XIII wieku (ryc. 6) (Chudziak, Noryśkiewicz A., Noryśkiewicz B. 2004, s. 214, ryc. 4, 5). Sytuacja polityczna Chełmna w 1. ćwierci XIII wieku zmieniała się dynamicznie. W latach 1216-1217 ośrodek ten uległ zniszczeniu przez Prusów, a już w 1223 roku został nadany Chrystianowi i ponownie przywrócony do rangi kasztelanii ${ }^{4}$. W 1228 roku gród wraz z przynależnościami został przekazany Krzyżakom. Jak wiadomo, miasto lokacyjne z 1233 roku zlokalizowane zostało około $2 \mathrm{~km}$ na południe od wspomnianego miejsca, na terenie dzisiejszego Starogrodu (ryc. 7), a następnie, w wyniku co najmniej dwóch translokacji, pierwszej w 1239 roku na teren Rybaków, dzisiejszej dzielnicy Chełmna oraz drugiej, zapewne około 1250 roku, znalazło się w obecnym miejscu (Jasiński 1980, s. 44). Dotychczasowy, słabo zaawansowany stan rozpoznania archeologicznego zespołu

${ }^{4}$ W latach 1224-1225 gród uległ ponownemu zniszczeniu w wyniku nowego najazdu pruskiego, a znaczna część ziemi chełmińskiej mogła dostać się pod zwierzchnictwo pruskie (Jasiński 1982, s. 15). Stopień podporządkowania ziemi chełmińskiej i zasięg penetracji pruskiej był wielokrotnie dyskutowany w literaturze historycznej (por. m.in. Powierski 1968; Bieniak 1970). 


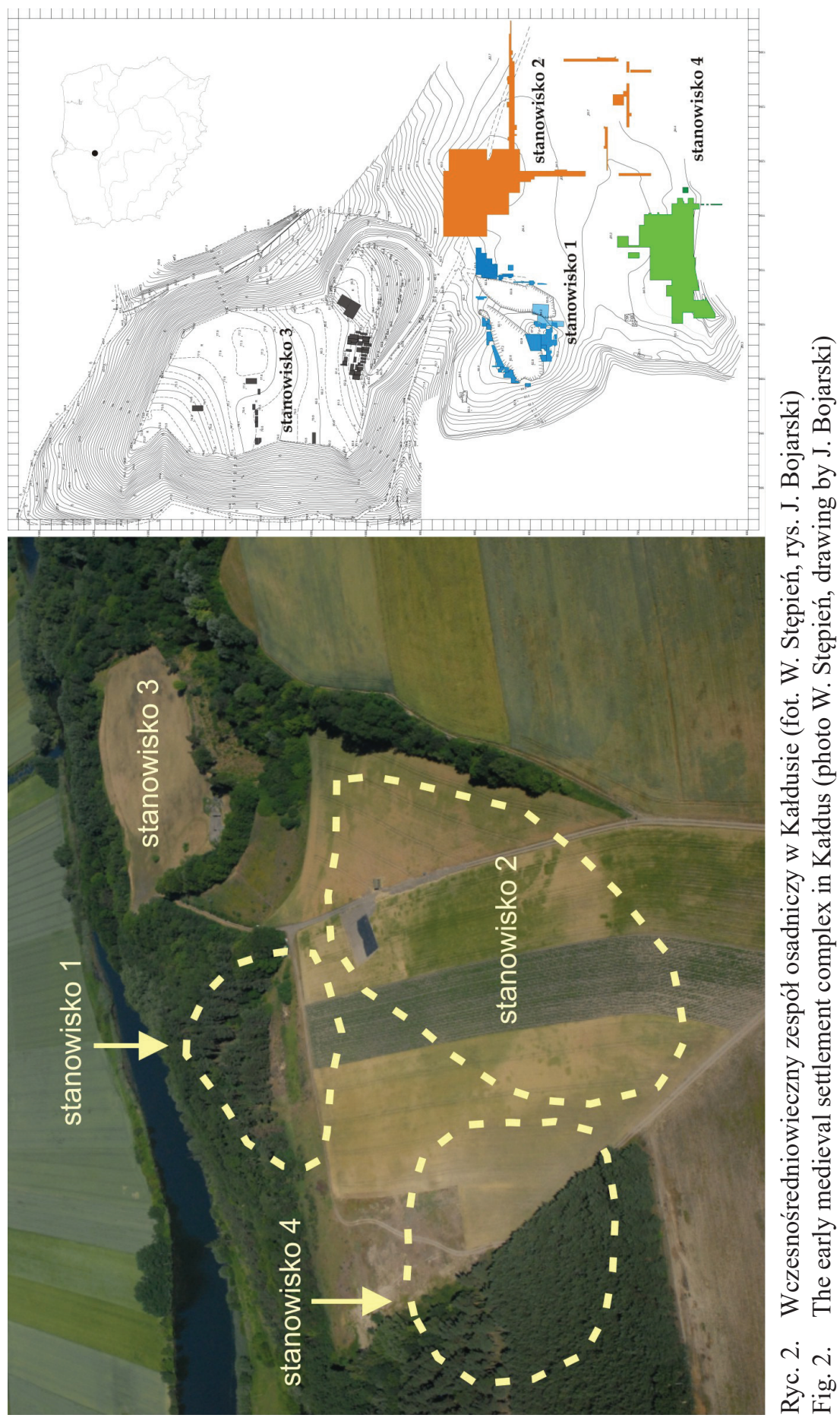



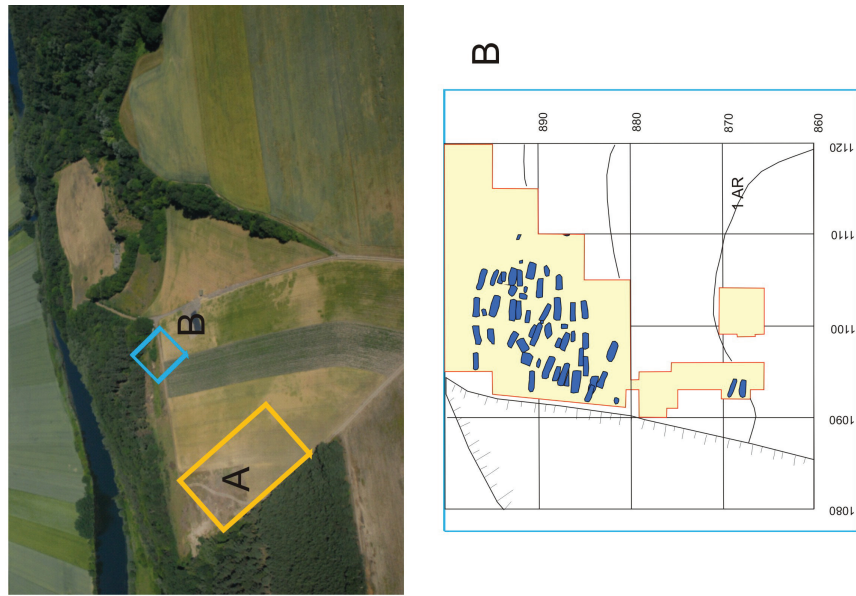

营茪

:

. क

in

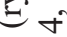

음

a

$3<$

焉 总

ค J

† 를

\%

告

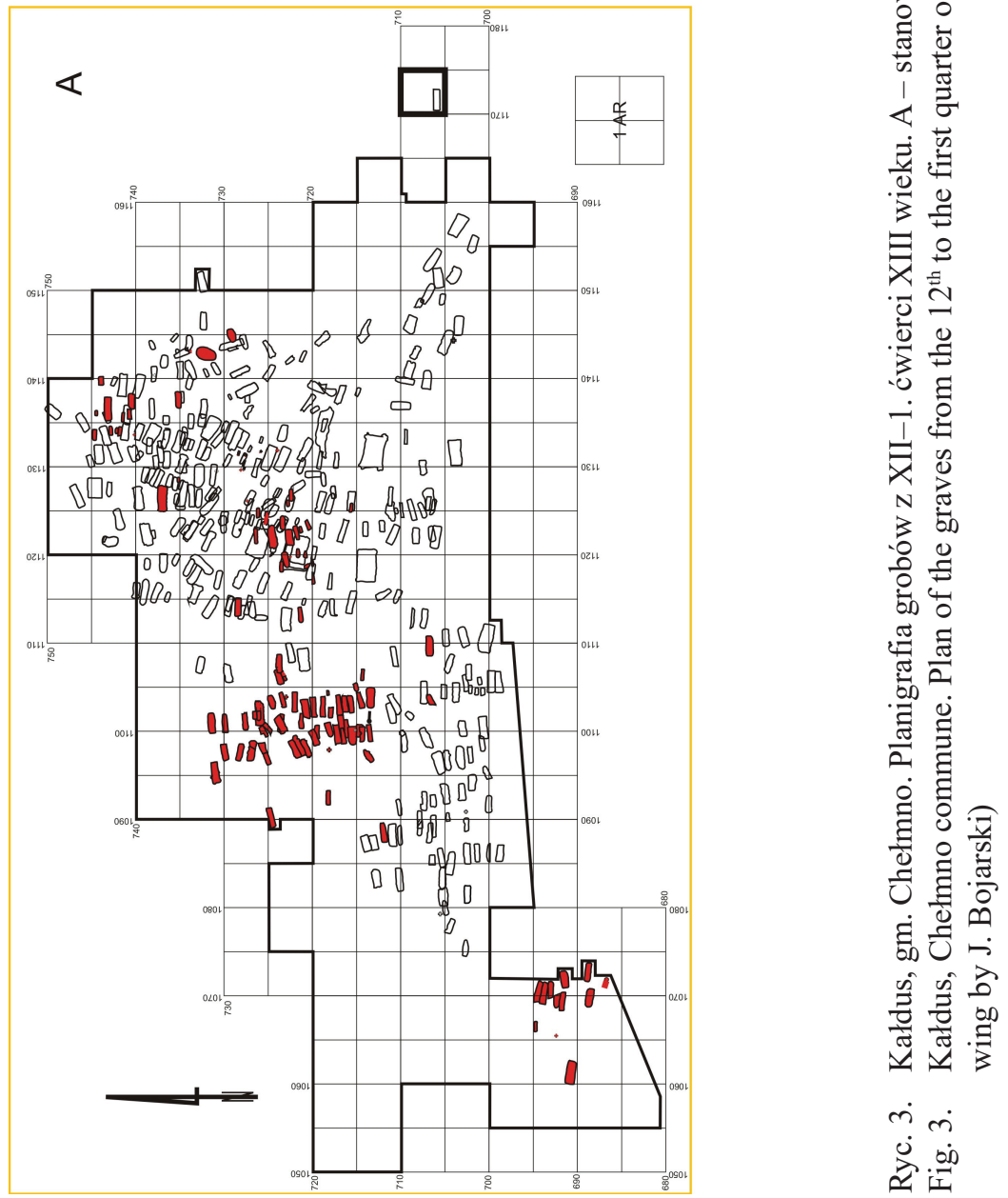



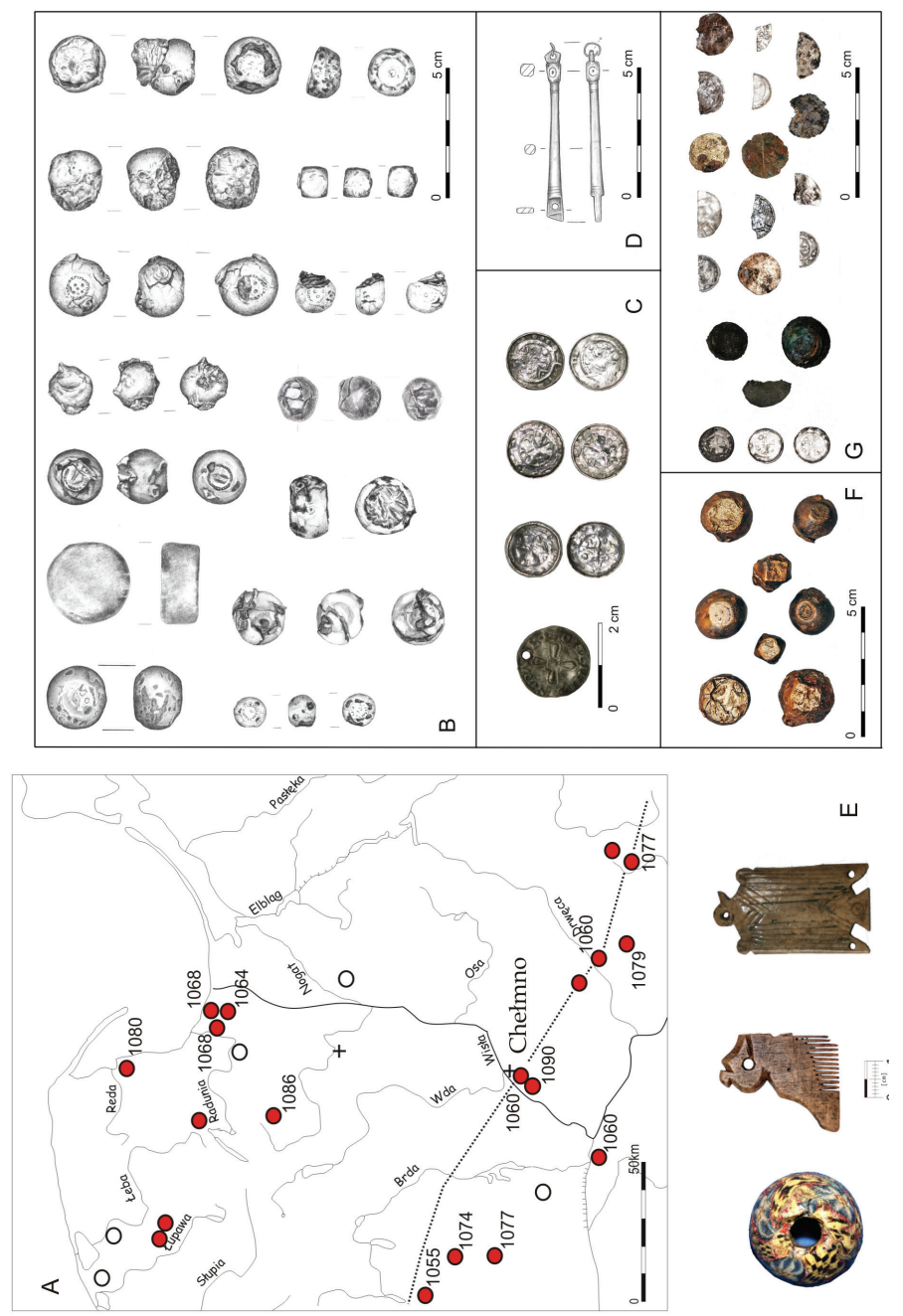

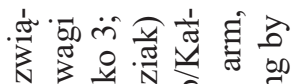

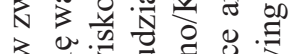

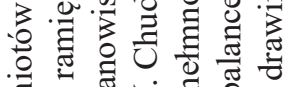

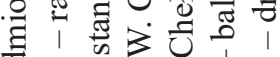
总昰式 르를

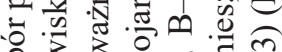
خे 矛

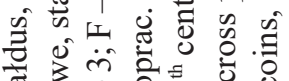
స ह

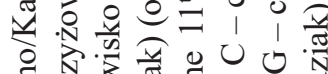

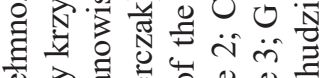

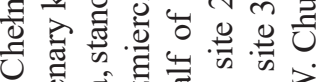

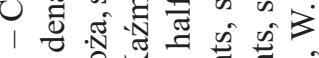

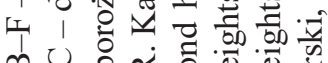
๓ 0 ¿

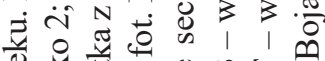
造造造

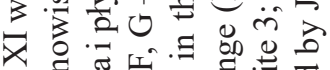

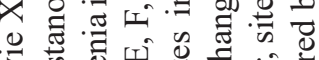

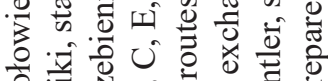

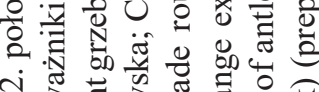
ن 施

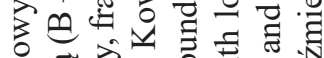
을 帘

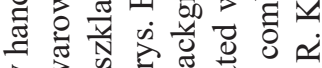
3 300

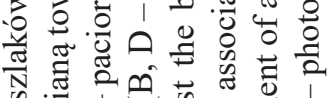

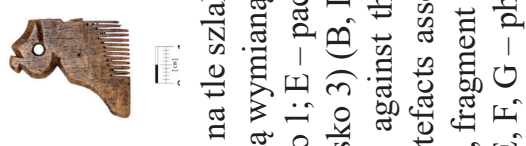

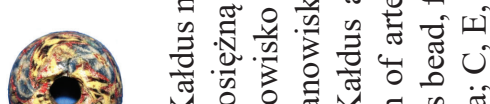

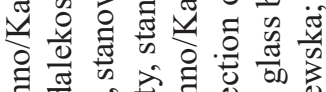

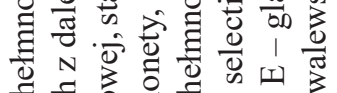

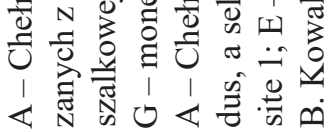

$\begin{array}{ll}\dot{0} & \dot{0} \\ \dot{0} & \dot{0}\end{array}$ 


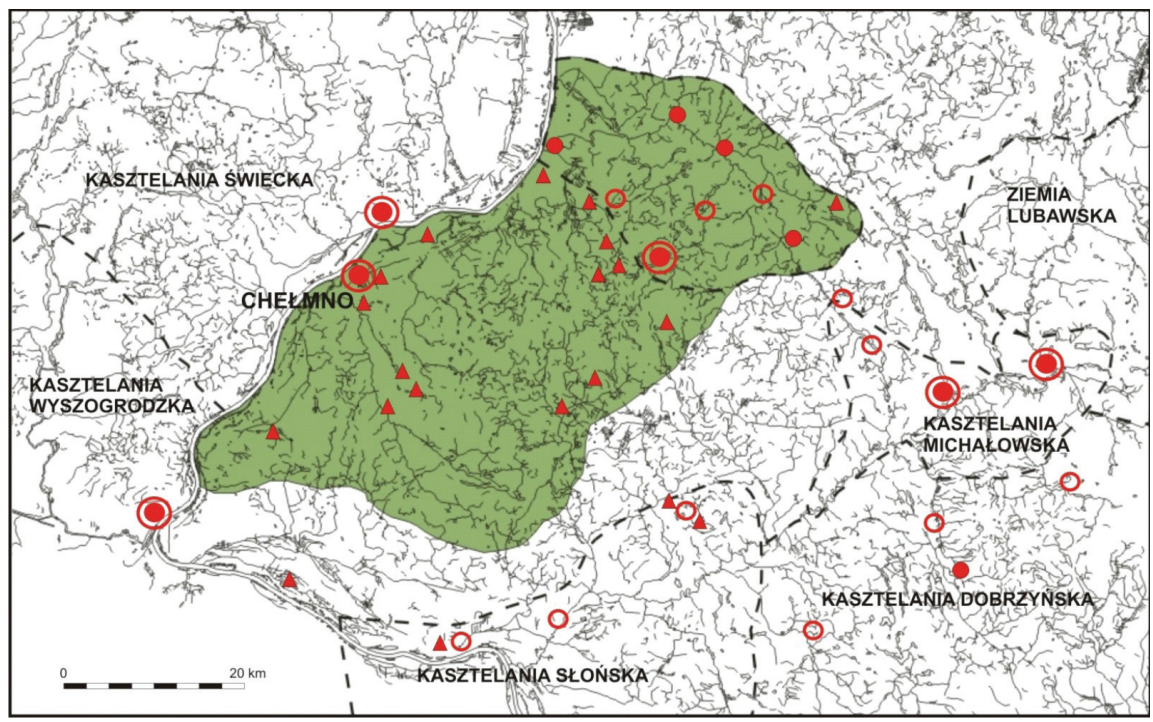

Ryc. 5. Zasięg kasztelanii chełmińskiej w 2. połowie XII i 1. ćwierci XIII wieku (oprac. W. Chudziak)

Fig. 5. Range of Chełmno castellany in the second half of the $12^{\text {th }}$ and the first quarter of the $13^{\text {th }}$ century (prepared by W. Chudziak)

osadniczego w Starogrodzie nie pozwala na szczegółowe wnioskowanie (Kola 1972; 1974) $)^{5}$, tym niemniej znane z tego obszaru materiały źródłowe wskazują na intensywne użytkowanie u schyłku wczesnego średniowiecza terenu położonego wokół dzisiejszego Starogrodu, stanowiącego miejsce pierwszej lokacji miasta (Starogród, stanowisko 1$)^{6}$.

Uboższą bazą źródeł pisanych i archeologicznych charakteryzuje się Toruń (łac. Thorun $)^{7}$. Nazwa tego ośrodka nie była wzmiankowana w źródłach

5 Pierwsze badania wykopaliskowe na terenie zamczyska przeprowadził w latach 1963-1964 January Janikowski z Muzeum Okręgowego w Toruniu. Kolejne prace pod kierunkiem A. Koli z Katedry Archeologii UMK w Toruniu miały miejsce w latach 1969-1970. W ich trakcie założono trzy wykopy na terenie przedzamcza II. Również tym razem natrafiono w późnośredniowiecznych nawarstwieniach kulturowych na ułamki naczyń datowanych na XII-początek XIII wieku, świadczące o wcześniejszym, przedkrzyżackim osadnictwie (Kola 1974, s. 200).

${ }^{6}$ Na terenie dawnego zamku krzyżackiego w Starogrodzie (stanowisko 1) oraz w najbliższym jego otoczeniu - głównie wzdłuż krawędzi wysoczyzny oraz u jej podnóża - odkryto szereg stanowisk archeologicznych z materiałami źródłowymi datowanymi na młodsze fazy wczesnego średniowiecza (stanowiska 2, 4, 6 i 8; por. Bienias 2004, ryc. 8).

7 Znaczenie Torunia w okresie wczesnego średniowiecza trafnie scharakteryzował T. Jasiński: „Trzeba przy tym pamiętać, iż zarówno okolice osady Stary Toruń, jak i rejon obecnego miasta, jakkolwiek nie były pustkami osadniczymi, to jednak nie odgrywały większej roli w dziejach Kujaw i Mazowsza. Toruń nie został ani razu wymieniony w źródłach pisanych w okresie przedkrzyżackim. Nie stanowił on centrum administracyjnego, nic też nie wiemy, nawet na podstawie źródeł archeologicznych, aby w Toruniu była jakaś osada targowa, nie mówiąc o kolonii kupców" (Jasiński 1999, s. 102). 


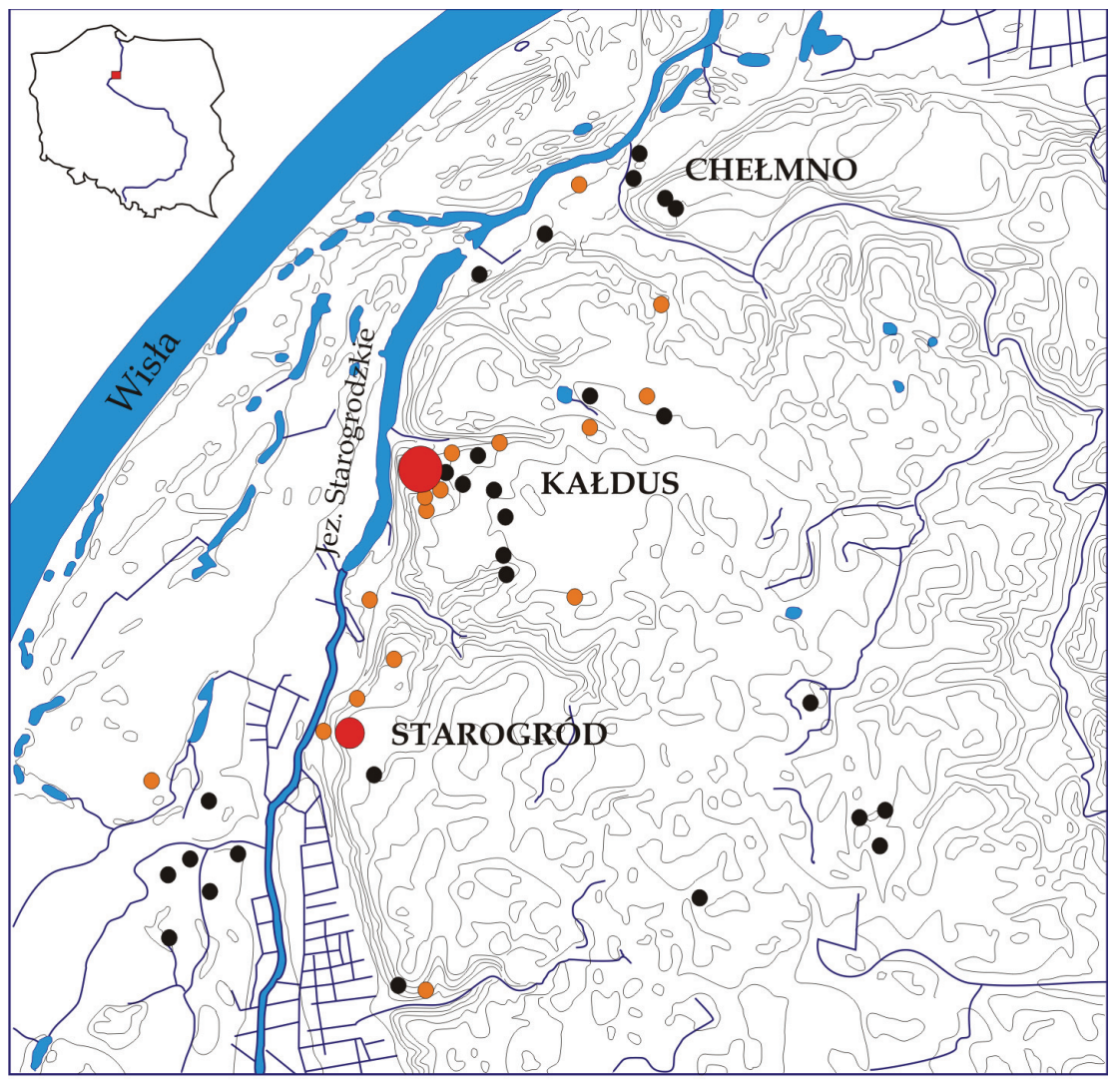

- stanowiska z VII-XI w.

- stanowiska z XII-XIII w.

Ryc. 6. Wczesnośredniowieczne struktury osadnicze związane z Chełmnem (oprac. J. Bojarski)

Fig. 6. Early medieval settlement structures associated with Chełmno (prepared by J. Bojarski)

dotyczących ziemi chełmińskiej, na przykład w dokumencie z Lonyz z 1223 roku. Jej źródłosłów nie jest jasny, najczęściej przyjmuje się, że pochodzi od prasłowiańskiego tor 'utarta droga' lub łączy się z podobnymi w brzmieniu nazwami Tarnów czy Tarnowo (Jasiński 1981, s. 11-12 - tam literatura na ten temat). Pierwotna lokalizacja osiedla o tej nazwie dotyczyła miejsca leżącego naprzeciwko grodu w Nieszawie, po drugiej stronie Wisły, zapewne na terenie dzisiejszego Starego Torunia, znajdującego się bezpośrednio przy starej przeprawie wiodącej wzdłuż rzeki Wierdzelew (Zielona), łączącej Kujawy z ziemią chełmińską (ryc. 8). Przeprawa funkcjonowała w tym miejscu już w XI wieku, a dowodnie użytkowana była jeszcze przez krzyżowców w czasie kampanii w 1223 roku (Powierski 1968, s. 158; Jasiński 1982, s. 14). Jej militarne znaczenie podkreśla lokalizacja po 

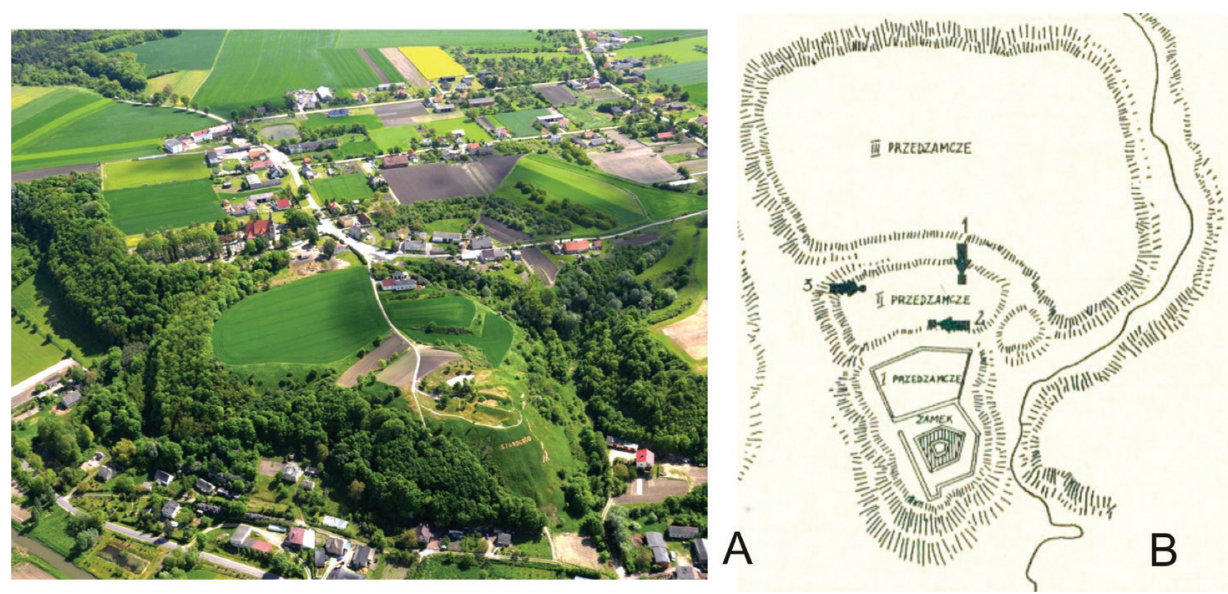

Ryc. 7. Starogród, gm. Chełmno. A - zespół osadniczy (fot. W. Stępień); B - plan grodziska na podstawie szkicu T. Ch. Gisego (wg Kola 1974)

Fig. 7. Starogród, Chełmno commune. A - settlement complex (photo W. Stępień); B - plan of stronghold based on Gise's sketch (after Kola 1974)

północnej stronie Wisły miejscowości Przysiek, a po południowej Osiek Wielki. W najbliższej okolicy Starego Torunia występują liczne nazwy polskie znane ze źródeł pisanych XIII- i XIV-wiecznych, między innymi Kępa Górska, Kępa Wierzbska, las Dąbrowa, Górsk, Smolno, Łukowo, Drzonowo, które odnieść należałoby zapewne do czasów poprzedzających przybycie Krzyżaków (Jasiński 1980, s. 17). Znajduje to swoje potwierdzenie na mapie zasiedlenia południowej części ziemi chełmińskiej w okresie wczesnego średniowiecza (Chudziak 1996, mapa I). Kronikarz krzyżacki Piotr Dusburg przekazał informacje na temat wzniesionej przez siedmiu braci zakonnych w 1231 roku budowli, zlokalizowanej bezpośrednio nad Wisłą na „,pewnym dębie, na którym dla obrony postawiono obwarowania i mury" (Jasiński 1999, s. 111, przypis 16). Ta niekoniecznie mityczna informacja, potwierdzona przez inne źródła, wskazywałaby, że pierwsza siedziba Krzyżaków na ziemi chełmińskiej wzniesiona została na tzw. surowym korzeniu ${ }^{8}$. Przy tym dębie miało powstać pierwsze miasto, które jak informuje Dusburg ,z powodu ustawicznego przyboru wód zostało przeniesione na to miejsce, gdzie zarówno zamek, jak i miasto Toruń znajduje się obecnie”. Dotychczasowe badania archeologiczne o niewielkim zakresie, prowadzone w tej okolicy, nie przyniosły rozstrzygających rezultatów co do identyfikacji tego miejsca. Na terenie miejscowości Stary Toruń odkryto podczas badań powierzchniowych i sondażowych jedynie pozostałości osady z wczesnego średniowiecza, datowanej przez R. Uziembło na XI-XII wiek ${ }^{9}$.

\footnotetext{
${ }^{8}$ Nie oznacza to jednak, że obszar ten był zupełnie wyludniony, czemu przeczyłoby występowanie wspomnianych nazw polskich miejscowości na zachód od Starego Torunia oraz znacznych rozmiarów osady badanej archeologicznie (por. niżej).

9 Sprawozdanie z badań (z roku 1982) znajduje się w archiwum WKZ Toruń.
} 


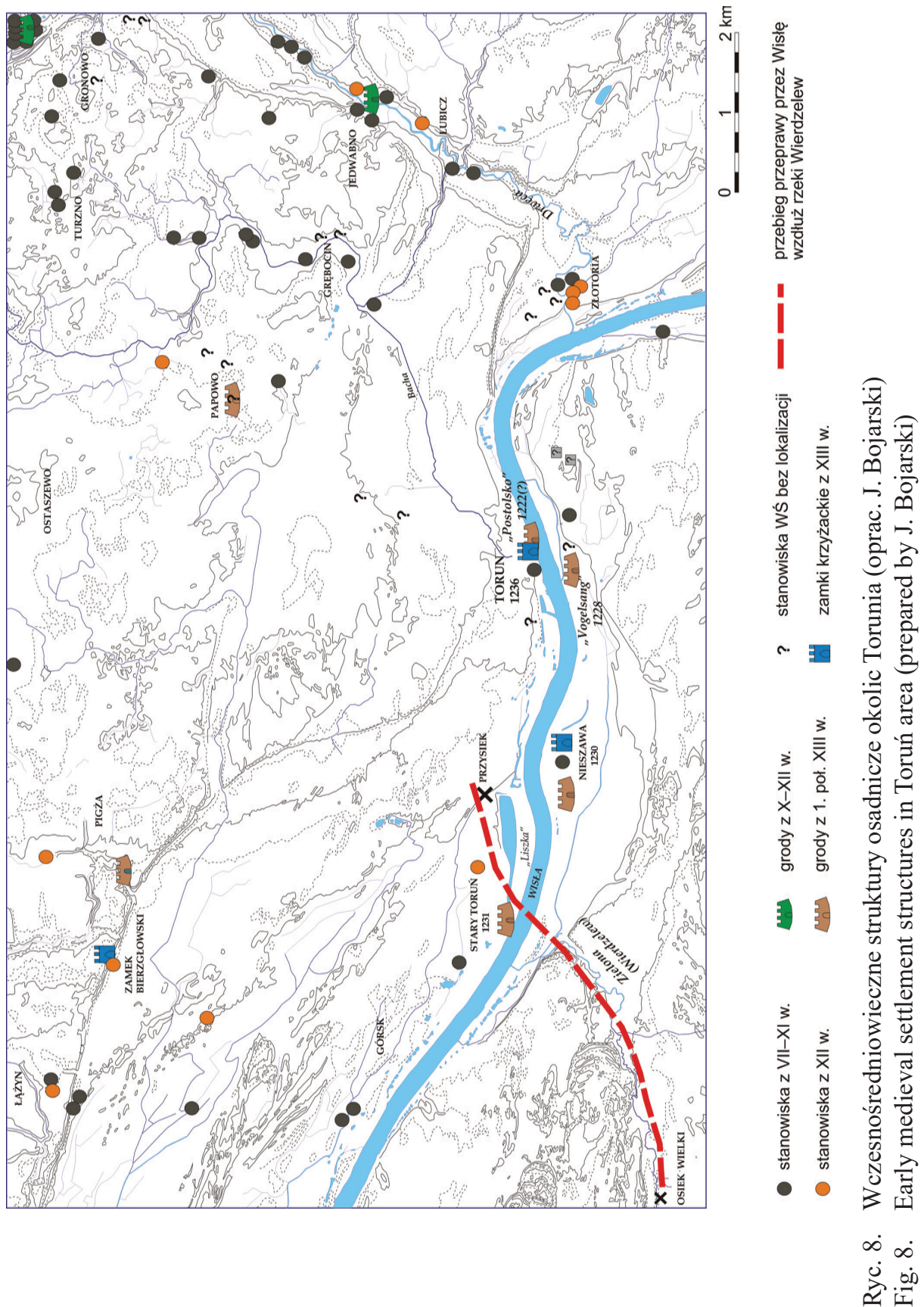


Nie stwierdzono śladów jakichkolwiek średniowiecznych obwarowań, choć wiele przesłanek wskazuje, jak to przekonywująco wykazał T. Jasiński, że gród krzyżacki znajdował się tam, gdzie kościół św. Jana Chrzciciela w Starym Toruniu, wzmiankowany jeszcze w połowie XVIII wieku (Jasiński 1999, s. 120 i nn.). Według J. Powierskiego obszar obecnego miasta leżał na peryferiach kasztelani słońskiej, wchodząc jednocześnie w zakres złotoryjskich posiadłości biskupstwa włocławskiego (Powierski 1977, s. 90-96). Część tego terenu została wydzierżawiona miastu przez biskupa w 1258 roku, a granica posiadłości kościelnych rozciągała się na wschód i północny wschód od tzw. Biskupiej Góry, tj. wzniesienia położonego w rejonie dzisiejszego kościoła św. Katarzyny (Jasiński 1982, s. 21). Istnienie wyraźnej rubieży osadniczej w XII-1. połowie XIII wieku potwierdzają wyniki badań archeologicznych. Poza pojedynczymi punktami osadniczymi, nie stwierdzono tu wyodrębniającego się skupiska osad wczesnośredniowiecznych (ryc. 8). Najbliższe z nich położone są w okolicach Czarnowa - Rzęczkowa, przy szlaku dalekosiężnym prowadzącym z Gniezna do Prus oraz nad dolną Drwęcą, w okolicach Jedwabna - Lubicza - Złotorii, te zaś w XII wieku związane były, jak już wyżej wspomniano, z dobrami biskupa włocławskiego (Chudziak 1996, ryc. 5, 6). Nie można wykluczyć, że obraz ten jest wynikiem po części niewystarczającego stanu archeologicznego rozpoznania sieci osadniczej lub zniszczenia stanowisk w wyniku erozji lub ich przykrycia grubymi warstwami osadów rzecznych akumulowanych $w$ trakcie powodzi (jedna $z$ nich miała miejsce w latach 80 . XVIII wieku, wówczas jakoby miały zniknąć ostatnie resztki zabudowań pokrzyżackich w Starym Toruniu) (Jasiński 1999, s. 123).

Zagrożenie stałym zalewaniem wodami Wisły było głównym powodem, dla którego Krzyżacy zdecydowali się na przeniesienie miasta 9 km na wschód, w górę Wisły, w miejsce obecnego Starego Miasta. Do tego celu wybrano obszar znajdujący się na cyplu krawędzi terasy nadzalewowej, bezpośrednio przy dawnej warowni, w obrębie której wybudowano w latach 40. XIII wieku ceglany zamek. Budowa twierdzy krzyżackiej nawiązywała formą do starszego założenia, o czym świadczy podkowiasty układ murów zamku, wzniesionych na wałach grodu o takim właśnie przebiegu (ryc. 9). Wiele wskazuje na to że, we wczesnym średniowieczu znajdował się tu przewóz przez rzekę, umożliwiający transport pomiędzy obiema stronami Wisły, użytkowany alternatywnie do przeprawy w Starym Toruniu (Jóźwiak 1996). Miejsce to identyfikowane jest z wymienionym w dokumencie z Lonyz grodem Postolsko, nadanym przez Konrada Mazowieckiego biskupowi Chrystianowi w 1222 roku (Powierski 1973, s. 27-32). Domysł ten jest o tyle wiarygodny, że nazwą Postolsko określali mieszkańcy miasta sztucznie przekopaną Strugę Toruńską (Bacha), która uchodziła do Wisły obok dawnego grodu (Jasiński 1981, s. 18).

Nawarstwienia wczesnośredniowieczne odkryte na wzgórzu zamkowym świadczą o istnieniu tu osady wiejskiej z X-XII wieku i warowni pobudowanej 


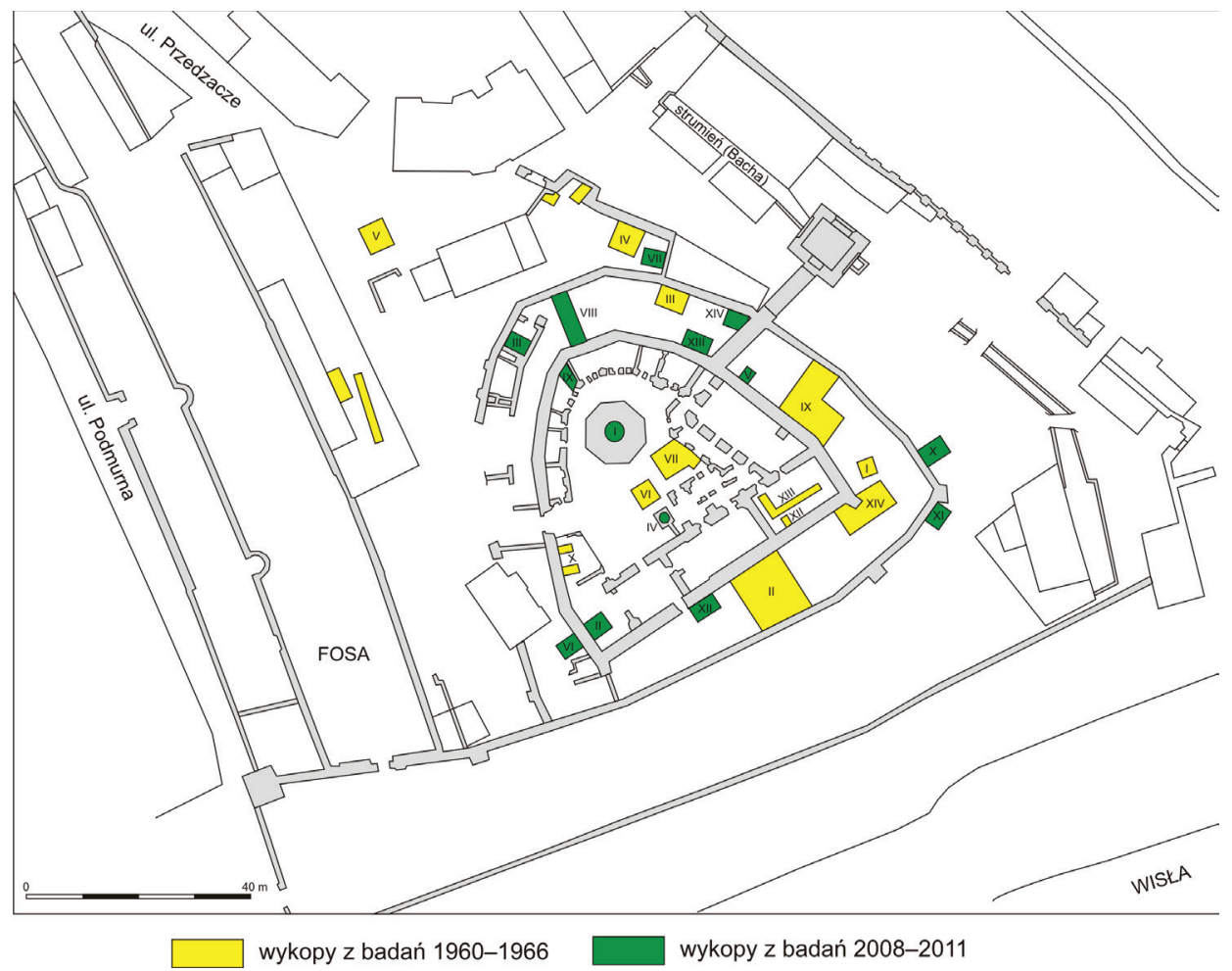

Ryc. 9. Toruń, stanowisko 1. Zakres prac archeologicznych (oprac. J. Bojarski) Fig. 9. Toruń, site 1. Range of archaeological work (prepared by J. Bojarski)

być może jeszcze w XII stuleciu, funkcjonującej w 1. ćwierci XIII wieku (ryc. 10), jak mogłyby wskazywać materiały ceramiczne występujące w warstwach podwałowych i w obrębie samego wału (Chudziakowa 1994, s. 172; ryc. 183, 184). Badania prowadzone w ostatnich latach na zamku nie przyniosły właściwie nowych ustaleń w tej kwestii ${ }^{10}$. Z warstwy próchnicznej, zalegającej poniżej nawarstwień związanych z budową i użytkowaniem zamku krzyżackiego, pozyskano jednorodny, pod względem stylistyczno-morfologicznym, zbiór naczyń ceramicznych, datowanych na 2. połowę XII-1. ćwierć XIII wieku (ryc. 11). Warstwa ta, o miąższości dochodzącej miejscami do 30-40 cm, występowała praktycznie na

${ }_{10}$ Prace wykopaliskowe prowadzone w latach 2008-2011 w ramach projektu realizowanego pod kierownictwem dr. Adama Chęcia z Instytutu Archeologii UMK w Toruniu nie wniosły niczego nowego do wiedzy na temat przedkrzyżackiego rozwoju zasiedlenia wzgórza zamkowego. W ich trakcie założono 14 wykopów badawczych, rozlokowanych w obrębie murów obwodowych zamku oraz po ich stronie zewnętrznej. Nigdzie nie natrafiono na pozostałości wałów grodu, a jedynie na warstwę kulturową, powstałą w wyniku zniwelowania reliktów zabudowy mieszkalnej z okresu bezpośrednio poprzedzającego budowę murowanego zamku krzyżackiego. Dokumentacja z tych badań znajduje się w archiwum Wojewódzkiego Urzędu Ochrony Zabytków w Toruniu oraz w Instytucie Archeologii UMK. 

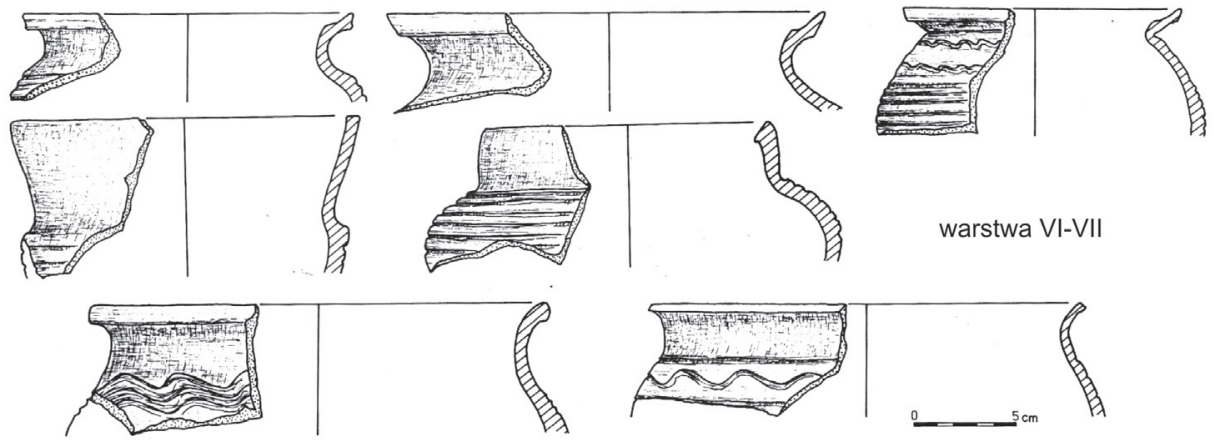

warstwa VI-VII
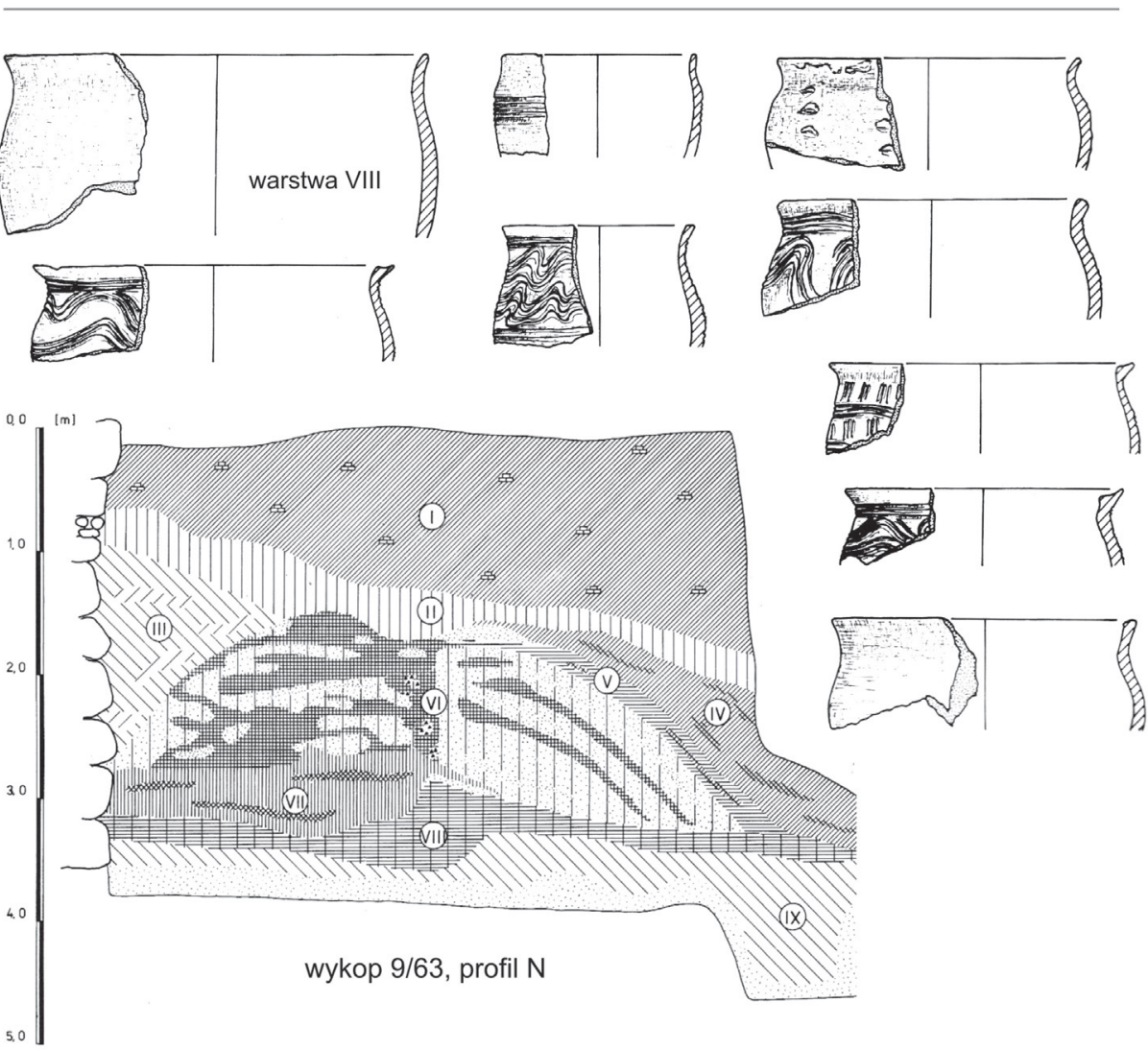

Ryc. 10. Toruń, stanowisko 1. Wybór wczesnośredniowiecznych naczyń ceramicznych pozyskanych podczas badań prowadzonych w 1963 roku i przekrój przez wał grodziska (wg Chudziakowa 1994)

Fig. 10. Torun, site 1 . Selection of early medieval pottery vessels acquired during excavations conducted in 1963 and section of stronghold's ramparts (after Chudziakowa 1994) 

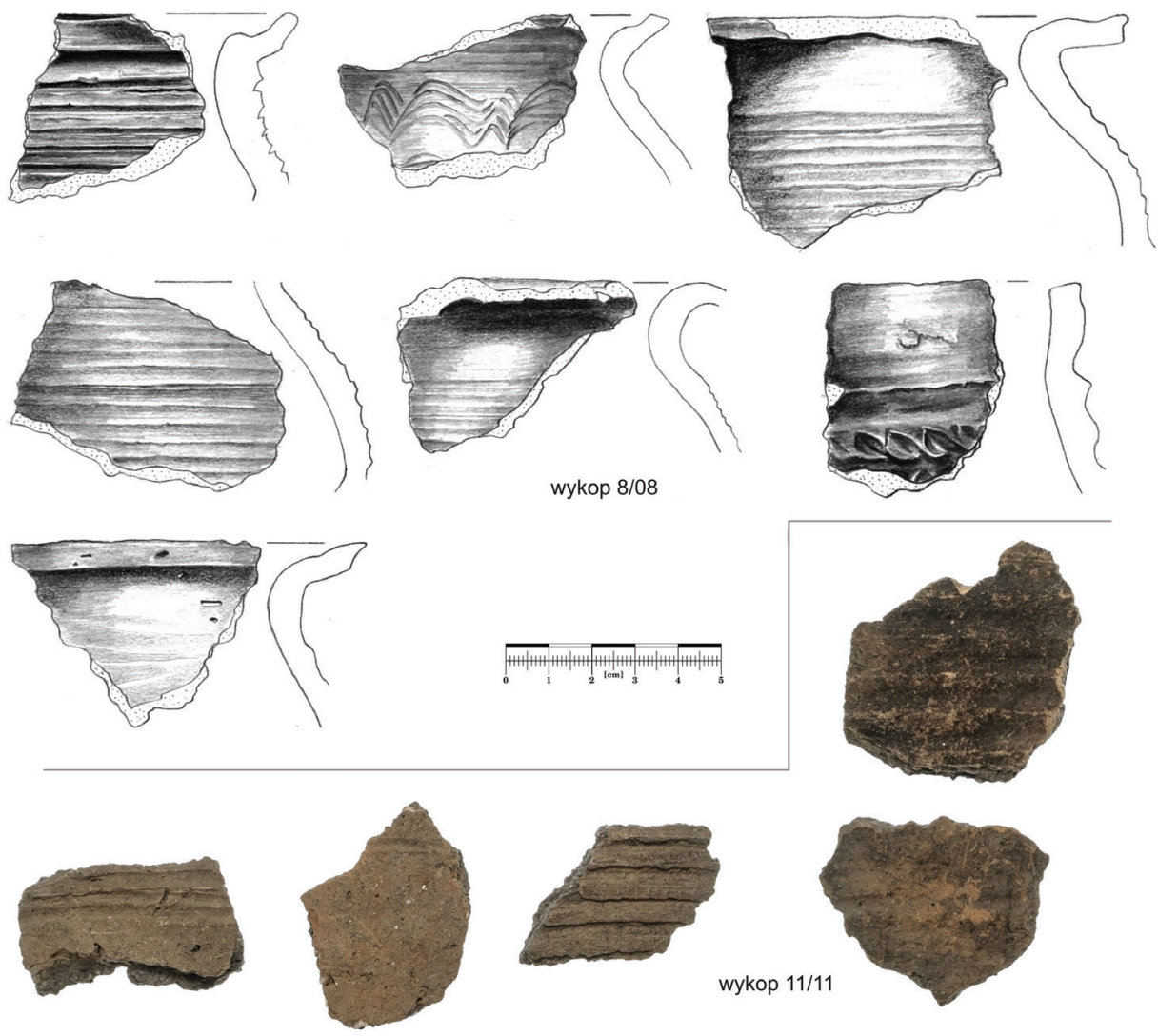

wykop 11/11
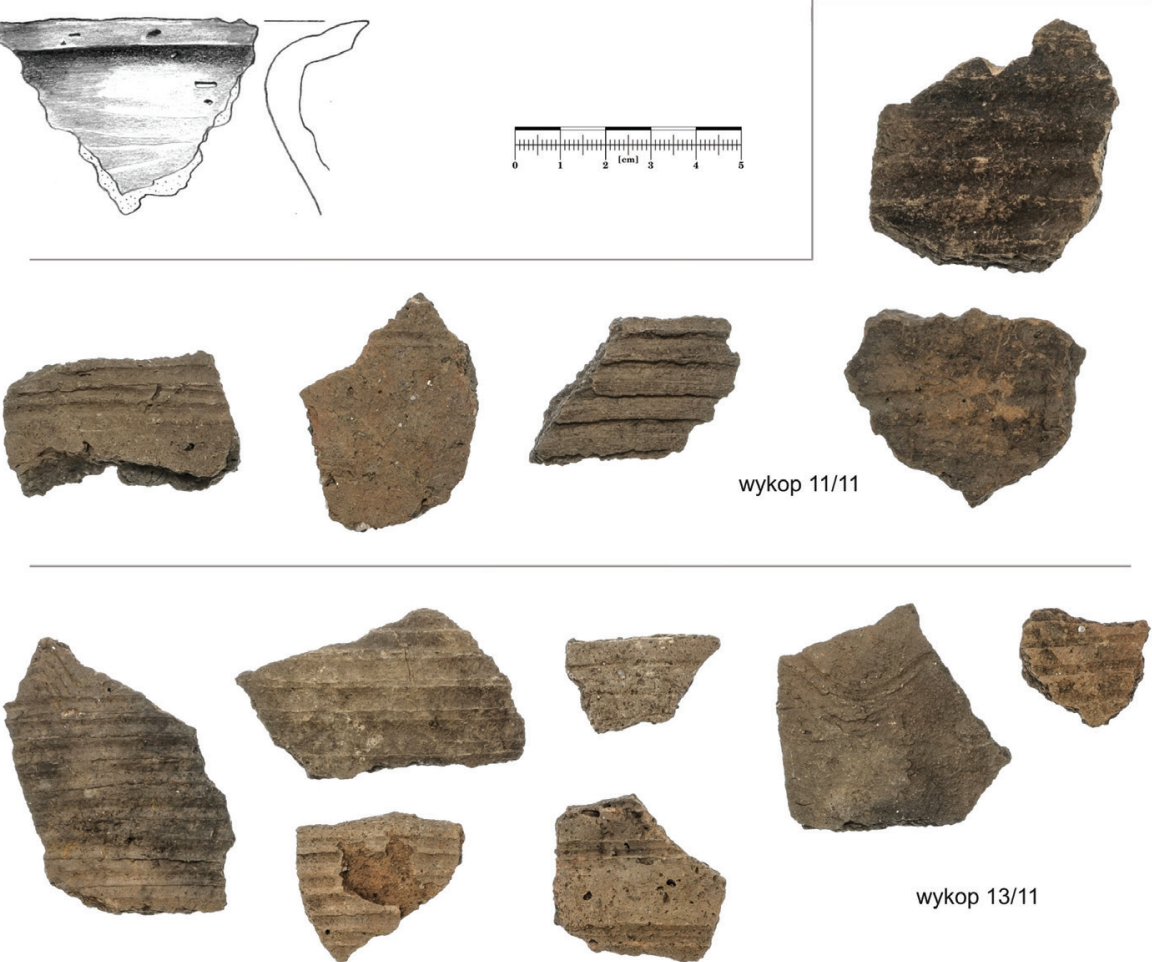

wykop 13/11

Ryc. 11. Toruń, stanowisko 1 . Wybór ułamków naczyń ceramicznych z badań prowadzonych w latach 2008-2011. A - wykop 8/08, B - wykop 11/11, C - wykop 13/11 (A - rys. M. Przybylska; B, C - fot. W. Ochotny)

Fig. 11. Toruń, site 1. Selection of pottery fragments from excavations conducted in 2008-2011. A - trench 8/08, B - trench 11/11, C - trench 13/11 (A - drawing by M. Przybylska; B, C - photo W. Ochotny) 

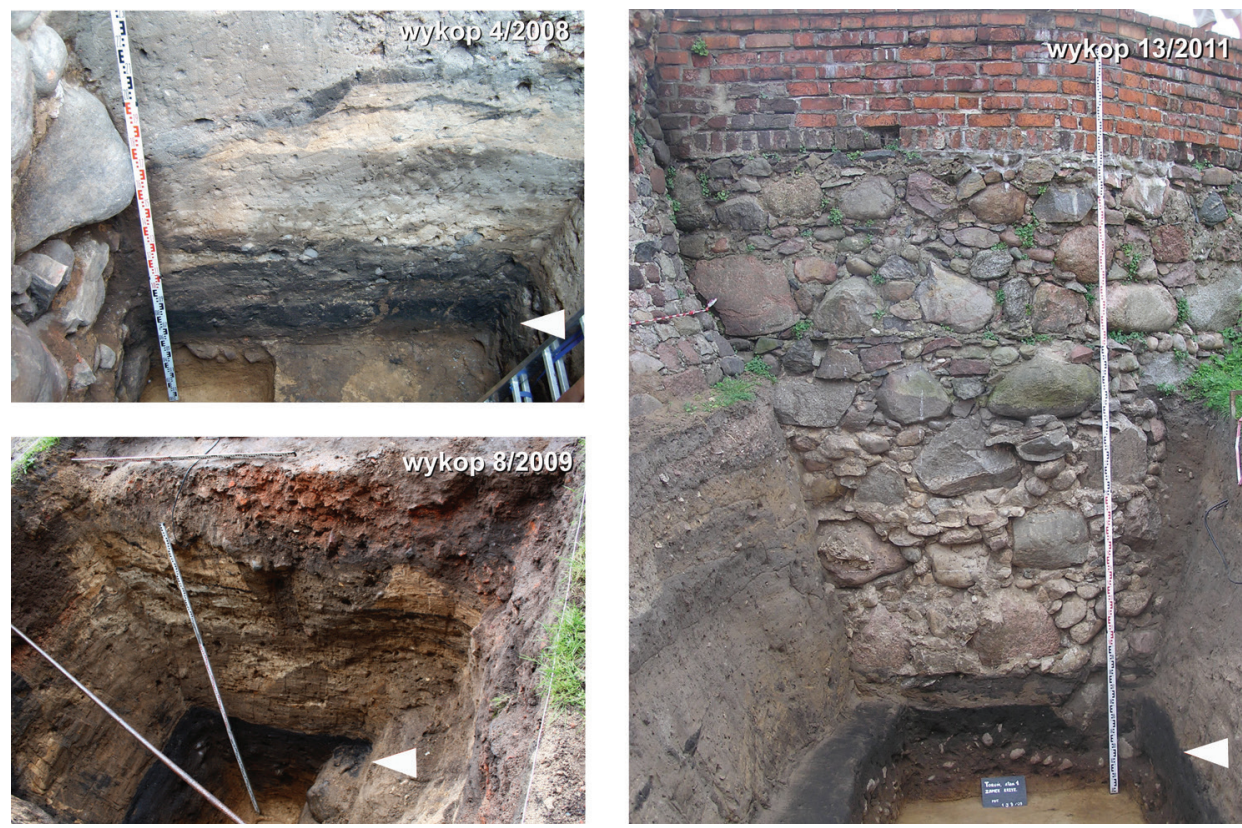

Ryc. 12. Toruń, stanowisko 1. Stratygrafia wykopów 4/08, 8/09 i 13/11 z uchwyconym wczesnośredniowiecznym poziomem osadniczym (fot. A. Chęć, J. Struwe)

Fig. 12. Torun, site 1 . Stratigraphy of trenches $4 / 08,8 / 09$ and $13 / 11$ with perceptible early medieval settlement level (photo A. Chęć, J. Struwe)

całym badanym terenie (ryc. 12). Do określenia czasu jej powstania wykorzystano też analizę radiowęglową próby węgli drzewnych (pobraną z wykopu II/2008); uzyskano datę $1050 \pm 50 \mathrm{BP}^{11}$.

Warownia przedkrzyżacka wpisuje się swoim charakterem (wielkość, położenie, inwentarz zabytków) w horyzont grodów strażniczych powstałych w okresie krucjat pruskich na pograniczu ziemi chełmińskiej i pruskiej Pomezanii; takie obiekty-strażnice funkcjonowały zwłaszcza nad Osą - w Jabłonowie, Pokrzywnie i Grudziądzu (ryc. 13). Z historycznego punktu widzenia prawdopodobne jest, że gród w Toruniu (identyfikowany z Postolskiem) został pobudowany w 1. ćwierci XIII wieku, a najpewniej w 2. dekadzie XIII wieku w związku z nasilającym się zagrożeniem pruskim na północno-zachodnim pograniczu mazowieckim. Jednak podobnie jak w Starym Toruniu, również i w tym miejscu nie odkryto archeologicznych śladów istnienia osady rzemieślniczo-handlowej, ani też zaplecza osadniczego charakterystycznego dla ośrodków wczesnomiejskich. Ewidentnie wskazuje na to brak materiałów źródłowych podobnych do tych z Kałdusa; nie znaleziono dotąd przedmiotów związanych $\mathrm{z}$ handlem i rzemiosłem, ani też luksusowych

${ }^{11}$ Datowanie wykonał prof. Marek Krąpiec w Laboratorium Datowań Bezwzględnych w Cianowicach. 
przedmiotów świadczących o przebywaniu tu elity władzy. Nie stwierdzono również żadnych nekropoli, których obecność byłaby logicznym dopełnieniem ośrodków osadniczych rangi ponadlokalnej. Najbliższe, wczesnośredniowieczne cmentarzyska związane są z naddrwęckimi skupiskami osadniczymi w Złotorii i Grębocinie - Papowie (niepewna jest natomiast chronologia grobów z Bydgoskiego Przedmieścia, które prawdopodobnie należy łączyć z późnym średniowieczem). Bogate i duże cmentarzysko z Brzozy Toruńskiej, położone na południowo-wschodnich peryferiach lewobrzeżnego Torunia, datowane na czasy Konrada Mazowieckiego, wchodziło w skład zespołu osadniczego w Otłoczynie (Zielonka 1974, s. 243). Nieliczne materiały źródłowe z wczesnego średniowiecza znalezione w kilku punktach miasta (okolice Ratusza Staromiejskiego ${ }^{12}$ i Krzywej Wieży), przy dużej skali ingerencji w nawarstwienia zalegające w obrębie Starego Miasta, świadczą raczej o słabo rozwiniętym zapleczu funkcjonującej tu w 1. ćwierci XIII wieku warowni, jak również w ogóle o zasiedleniu tego terenu przed lokacją miasta, z wyłączeniem wzgórza zamkowego. Najprawdopodobniej gród ten miał za zadanie strzec przeprawy przez Wisłę, stanowiąc wysunięty przyczółek na peryferiach kasztelanii słońskiej.

Na koniec spróbujmy raz jeszcze podsumować przedstawione wyżej ustalenia dotyczące genezy Chełmna i Torunia. Porównując przedlokacyjny etap rozwoju obu ośrodków widoczne są zasadnicze różnice między nimi, które wyeksponować można w kilku punktach.

1. Uwarunkowania środowiskowe: A - w przypadku Chełmna tereny pokryte żyznymi glebami sprzyjającymi rozwojowi rolnictwa; znaczący udział obszarów wylesionych; B - w przypadku Torunia przewaga gleb piaszczystych niskoenergetycznych, nie nadających się do upraw i generalnie niesprzyjających

${ }^{12} \mathrm{~W}$ ciągu ostatnich ponad 20 lat przeprowadzono na terenie Zespołu Staromiejskiego w Toruniu, w różnych jego punktach, mniej lub bardziej zaawansowane badania archeologiczne, których efektem było rozpoznanie nawarstwień z okresu powstania miasta (zdecydowaną większość prac o charakterze ratowniczym wykonała miejscowa firma Usługi Archeologiczno-Konserwatorskie Lidii Grzeszkiewicz-Kotlewskiej). Nigdzie, z wyjątkiem wspomnianego zamku krzyżackiego oraz okolic Krzywej Wieży (por. przypis 2), nie odkryto warstw kulturowych datowanych na wczesne średniowiecze. W każdym przypadku najstarsze poziomy użytkowe miasta średniowiecznego zalegały bezpośrednio na calcu, ewentualnie na nawarstwieniach datowanych na epokę brązu (kultura łużycka). Nawet na tzw. wtórnym złożu nie natrafiono na wczesnośredniowieczne materiały źródłowe, co byłoby normalnym zjawiskiem w przypadku występowania wcześniejszych śladów osadnictwa. Przykładem może być niedaleka Bydgoszcz, gdzie ułamki naczyń wczesnośredniowiecznych odkrywane są w wielu punktach Starego Miasta. Stąd wciąż niepotwierdzonym źródłowo, pozostaje stwierdzenie J. Chudziakowej o przedlokacyjnej zabudowie mieszkalnej w kwartale wokół kościoła św. św. Janów (Chudziakowa 1973, s. 69 i nn.; 1999, s. 79). Zresztą wątpliwości w tej kwestii wypowiedział swego czasu A. Kola, ograniczający wczesnośredniowieczną zabudowę przedlokacyjną wyłącznie do obszaru późniejszego zamku krzyżackiego (Jasiński 1981 s. 14, przypis 41). 


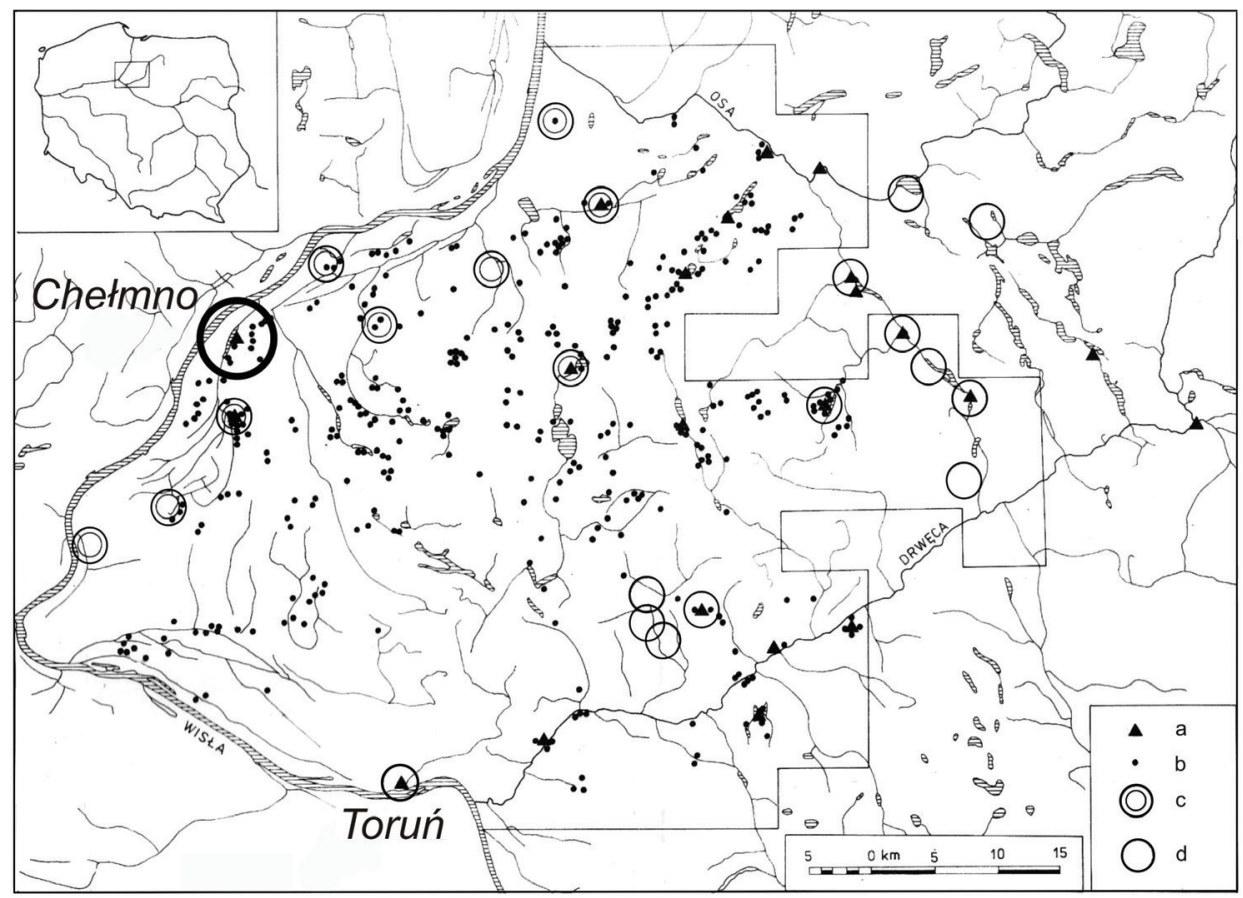

Ryc. 13. Rekonstrukcja sieci grodowej z terenu ziemi chełmińskiej na podstawie przywileju z Lonyz z 1222 roku (wg Chudziak 1993)

Fig. 13. Reconstruction of the stronghold network from Chełmno Land based on the privilege of Lonyz from 1222 (after Chudziak 1993)

osadnictwu ze względu na ówczesny poziom technik agrarnych, a także znaczący udział obszarów leśnych.

2. Położenie geopolityczne: $\mathrm{A}-\mathrm{w}$ przypadku Chełmna istnienie udokumentowanego w źródłach pisanych ośrodka kasztelańskiego; B - w przypadku Torunia (ale również Starego Torunia) brak źródeł pisanych potwierdzających jego wcześniejsze istnienie, usytuowanie na peryferii kasztelani słońskiej, w latach 1231-1233 przyczółek ziemi nieszawskiej należącej do Krzyżaków od 1230 roku.

3. Nazwa miejscowa: A - w przypadku Chełmna nazwa pojawia się w źródłach wcześniejszych (Culmen), etymologia jest ewidentnie słowiańska, lokalna; $\mathrm{B}$ - w przypadku Torunia nazwa wcześniej nie odnotowana w źródłach pisanych, zapewne przejęta przez Krzyżaków lub nadana przez nich z uwagi na przeprawę i trakt przebiegający przez Stary Toruń.

4. Lokalne struktury osadnicze: A - w przypadku Chełmna udokumentowane w źródłach archeologicznych i badaniach palinologicznych gęste osadnictwo wczesnośredniowieczne obejmujące zarówno okolice Kałdusa, jak i Starogrodu (tereny doliny oraz wysoczyzny); B - w przypadku Torunia (również Starego Torunia) zasadniczo brak rozwiniętych struktur osadniczych, pojedyncze punkty 
osadnicze oddalone od centrów zlokalizowanych nad dolną Drwęcą oraz w okolicach Czarnowa - Rzęczkowa - Złej Wsi;

5. Funkcje społeczne: A - w przypadku Chełmna potwierdzone archeologicznie funkcje charakterystyczne dla ośrodków wczesnomiejskich, przedkolacyjnych okresu wczesnego średniowiecza: rzemieślniczo-handlowe, religijne i administracyjno-militarne; B - w przypadku Torunia potwierdzone funkcje militarne, brak materialnych świadectw pozostałych funkcji.

6. Geneza ośrodka: A - w przypadku Chełmna Krzyżacy otrzymali gród z nadania Konrada i mimo translokacji nawiązali do tradycji istnienia ośrodka wcześniejszego, niewykluczone, że korzystając zapewne z potencjału mieszkańców miasta przedkolacyjnego; B - w przypadku Torunia miasto założono przy warowni wzniesionej według przekazu Dusburga na dębie, zapewne na tzw. surowym korzeniu, w sąsiedztwie osady wczesnośredniowiecznej, przeniesione następnie do Postolska, objęło tereny raczej niezasiedlone, ewentualnie słabo zaludnione, usytuowane na zapleczu niewielkiej pogranicznej warowni.

Wspólnym elementem obu pierwszych lokalizacji są uwarunkowania polityczno-komunikacyjne. Zarówno Chełmno, jak i Toruń położone były na pograniczu ziemi chełmińskiej, przy ważnych przeprawach, na skrzyżowaniu szlaków dalekosiężnych lądowych i wodnych, na wejściu do ziemi chełmińskiej od strony Kujaw i Pomorza (teoria ośrodków bramnych gateway) ${ }^{13}$. Oba ośrodki krzyżackie stanowiły zaczątek sieci miast włączonych później do Hanzy. Mimo jednego wspólnego dokumentu ich hierarchia była ściśle określona. Jeszcze w dokumencie z 1251 roku podkreślono nadrzędną, stołeczną rolę Chełmna, co nawiązywało zapewne do tradycji historycznej i szczególnej pozycji tego ośrodka, od którego przejęła nazwę cała ziemia chełmińska.

Rozpatrując genezę obu miast pod kątem potencjalnego continuum osadniczego na poziomie mezoregionalnym, uwzględniającym ich translokacje, należy stwierdzić dwa modele rozwoju:

I. Chełmno - kontynuacja funkcji ośrodka wczesnomiejskiego wraz z jego pierwotną nazwą ${ }^{14}$.

${ }^{13}$ Funkcje kontroli ruchu odbywającego się wzdłuż Wisły w okolicach dzisiejszego Torunia potwierdzałoby według T. Jasińskiego istnienie niewielkiej osady Trzeposz, położonej 1,5 km powyżej wzgórza zamkowego. Jej nazwa pierwotna miałaby brzmieć Przypust i pochodzić od prasłowiańskiego pripusti 'dopuścić', 'wpuścić', co oznaczałoby miejsce pobierania opłaty za możliwość wjazdu na określone terytorium (Jasiński 1981, s. 16 i nn.).

${ }^{14}$ Niewyjaśnione pozostają przyczyny, dla których zakon krzyżacki nie zdecydował się na budowę miasta wokół grodu in Culmine, czyli w miejscu pierwotnego Chełmna, wybrał zaś na miejsce lokacji najpierw Starogród, a potem położone bardziej na północ tereny obecnego miasta. Czyżby w grę wchodziły nierozwiązane wówczas kwestie własnościowe (pretensje do grodu biskupa Chrystiana lub któregoś z książąt?), czy może czynniki topograficzne? W taki sposób thumaczone były przyczyny translokacji Torunia na miejsce dzisiejszego miasta, dopiero po przekazaniu praw do terenów położonych przy grodzie przez biskupa włocławskiego (Jasiński 1981, s. 16). 
II. Toruń - lokacja miasta de facto na surowym korzeniu (chociaż obok wcześniej zasiedlonego wzgórza grodowego) wraz z nadaniem nowej nazwy lub przejęciem nazwy lokalnej osady (Stary Toruń); brak wcześniejszych tradycji urbanizacyjnych.

W chwili obecnej, w świetle posiadanych źródeł oraz stanu badań archeologicznych i historycznych, nic nie wskazuje, aby obraz ten miał się diametralnie zmienić w przyszłości, choć dalsze badania w tym zakresie wydają się niezbędne, co dotyczy zwłaszcza Torunia.

\section{Literatura}

Wykaz skrótów

MSL - Mons Sancti Laurentii, Toruń

Bieniak J.

1970 Studia nad dziejami ziemi chelmińskiej w okresie piastowskim, Rocznik Grudziądzki, t. 5/6, s. 5-69.

Bienias D.

2004 Polożenie fizjograficzne i chronologia stanowisk archeologicznych w Katdusie i w jego otoczeniu, [w:] Wczesnośredniowieczny zespót osadniczy w Kałdusie. Studia przyrodniczo-archeologiczne, red. W. Chudziak, MSL, t. 2, Toruń, s. 281-296.

Biskup M., Labuda G.

1986 Dzieje Zakonu Krzyżackiego w Prusach. Gospodarka - Społeczeństwo - Państwo - Ideologia, Gdańsk.

CDM

1919 Codex diplomaticus et commemorationum Masoviae generalis, t. 1, wyd. J. C. Kochanowski, Warszawa.

Chudziak W.

1996 Zasiedlenie strefy chetmińsko-dobrzyńskiej we wczesnym średniowieczu (VII-XI wiek), Torun.

1998 Wczesnośredniowieczny zespót osadniczy w Chelmnie, [w:] XII Sesja Pomorzoznawcza, Szczecin 23.-24. października 1997 r. Materiały, red. M. Dworaczyk, P. Krajewski, E. Wilgocki, Acta Archaeologica Pomoranica 1, Szczecin, s. 227-235.

2003a Wczesnośredniowieczna przestrzeń sakralna in Culmine na Pomorzu Nadwiślańskim, MSL, t. 1, Toruń.

2003b Wczesnośredniowieczne „importy” skandynawskie z Kałdusa pod Chetmnem na Pomorzu Wschodnim, [w:] Stowianie i ich sasiedzi we wczesnym średniowieczu, red. M. Dulinicz, Lublin-Warszawa, s. 117-126. 
2006a Chronologia cmentarzyska, [w:] Wczesnośredniowieczne cmentarzysko szkieletowe w Kałdusie (stanowisko 1), red. W. Chudziak, MSL, t. 3, Toruń, s.157-160.

2006b U źródel średniowiecznego miasta, [w:] Chetmno zabytkami malowane, red. M. Chełminiak, Bydgoszcz, s. 25-68.

Chudziak W., Bojarski J., Stawska V.

2010 Chronologia cmentarzyska, [w:] Wczesnośredniowieczne cmentarzysko szkieletowe w Kałdusie (stanowisko 4), red. W. Chudziak, MSL, t. 5, s. 105-120.

Chudziak W., Noryśkiewicz A., M., Noryśkiewicz B.,

2004 Zasiedlenie okolic Góry św. Wawrzyńca w ostatnich trzech tysiacach lat w świetle historii roślinności, [w:] Wczesnośredniowieczny zespót osadniczy w Kałdusie. Studia przyrodniczo-archeologiczne, red. W. Chudziak, MSL, t. 2, Toruń, s. 209-229.

Chudziakowa J.

1973 Badania nad średniowiecznym ośrodkiem miejskim na terenie Torunia w latach 1969-1972, Zapiski Historyczne, t. 38, z. 3, s. 75-77.

1976 Wczesnośredniowieczne osadnictwo na terenie Torunia w świetle źródet archeologicznych, Wiadomości Archeologiczne, t. 41, z. 1, s. 128-136.

1994 Toruń, [w:] Wczesnośredniowieczne grodziska ziemi chetmińskiej. Katalog źródet, red. J. Chudziakowa, Toruń, s. 170-174.

1999 Średniowieczny Toruń (w świetle źródel archeologicznych), [w:] Historia Torunia, t.1: W czasach średniowiecza (do roku 1454), red. M. Biskup, Toruń, s. $58-99$.

Chudziakowa J., Kola A.

1974 Źródla archeologiczne z terenu zamku krzyżackiego w Toruniu, Torun.

Czaja R.

2006 Pierwsze pięćset lat Chetmna (1232-1772), [w:] Chetmno zabytkami malowane, red. M. Chełminiak, Bydgoszcz, s. 69-196.

Jasiński T.

1980 Pierwsze lokacje miast nad Wista. 750 lat Torunia i Chetmna, Toruń.

1981 Poczatki Torunia na tle osadnictwa średniowiecznego, Zapiski Historyczne, t. 46, s. 5-34.

1982 Przedmieścia średniowiecznego Torunia i Chetmna, Poznań.

1999 Toruń XIII-XIV wieku - lokalizacja miast toruńskich i początki ich rozwoju (1231-około 1350), [w:] Historia Torunia, t.1: W czasach średniowiecza (do roku 1454), red. M. Biskup, Toruń, s. 100-166.

Jóźwiak S.

1996 Translokacje Chelmna a powstanie komturstwa staro- $i$ nowochetmińskiego, [w:] Studia nad dziejami miast i mieszczaństwa w średniowieczu, red. R. Czaja, J. Tandecki, Toruń, s. 83-94.

Kola A.

1972 Sprawozdanie z badań prowadzonych w Chetmnie i Starogrodzie, pow. Chelmno w latach 1968-1969, [w:] Komunikaty Archeologiczne. Badania 
wykopaliskowe na terenie województwa bydgoskiego w latach 1968-1969, Bydgoszcz, s. 104-109.

1974 Wyniki badań archeologiczno-sondażowych i ratowniczych przeprowadzonych na terenie Chetmna i Starogrodu, pow. Chetmno w latach 1969-1970, Acta Universitatis Nicolai Copernici, Archeologia 4, s. 167-201.

1975 Wczesnośredniowieczne Chełmno w świetle źródeł archeologicznych. Problem pierwotnej lokalizacji, maszynopis rozprawy doktorskiej w Instytucie Archeologii UMK, Toruń.

Musiałowski A.

2006 Monety, [w:] Wczesnośredniowieczne cmentarzysko szkieletowe w Kałdusie (stanowisko 1), red. W. Chudziak, MSL, t. 3, Toruń, s. 105-106.

2010 Analiza numizmatyczna wczesnośredniowiecznych monet, [w:] Wczesnośredniowieczne cmentarzysko szkieletowe w Kałdusie (stanowisko 4), red. W. Chudziak, MSL, t. 5, s. 139-157.

Nowak Z. H.

1987 Dzieje Chetmna do końca XVIII w., [w:] Dzieje Chetmna. Zarys monograficzny, wyd. 2, red. M. Biskup, Warszawa-Poznań-Toruń, s. 63-128.

Powierski J.

1968 Stosunki polsko-pruskie do 1230 roku ze szczególnym uwzględnieniem roli Pomorza Gdańskiego, Roczniki Towarzystwa Naukowego w Toruniu, R. 74, z. 1.

1971 Przekaz Dusburga o najazdach pruskich i przejściowej okupacji ziemi chetmińskiej, Komunikaty Mazursko-Warmińskie, nr 4/414, s. 379-427.

1973 Studia nad struktura administracyjno-terytorialna ziemi chetmińskiej i michałowskiej w okresie piastowskim, Bydgoskie Towarzystwo Naukowe, Prace Wydziału Nauk Humanistycznych, seria C, nr 13, Prace Komisji Historii 9, s. 3-86.

1977 Dobra ostrowicko-golubskie biskupstwa włocławskiego na tle stosunków polsko-krzyżackich w latach 1235-1308, Gdańsk.

Wąsowiczówna T.

1957 Wczesnośredniowieczne przeprawy przez środkowa Wisłę, Kwartalnik Historii Kultury Materialnej, R. 5, nr 3-4, s. 433-453.

Zielińska-Melkowska K.

1986 Przywilej chetmiński 1233 i 1251, [w:] Teksty pomników prawa chetmińskiego w przekładach polskich, nr 1, red. Z. Zdrójkowski, Torun.

Zielonka B.

1974 Cmentarzysko wczesnośredniowieczne w Brzozie, pow. Toruń, Acta Universitatis Nicolai Copernici, Archeologia 4, s. 235-244. 


\section{CHEŁMNO AND TORUŃ: THE ORIGINS OF TOWNS IN CHEŁMNO LAND}

Summary

The starting point for a discussion on the origins of towns in Chełmno Land is the content of the incorporation document issued in 1233 for Chełmno and Torun - called the Chełmno privilege - which become the source of the law system for the towns. The origins of both centres, however, were different and resulted from different settlement, cultural and economic conditions.

This paper discusses relations between newly incorporated towns (Chełmno and Toruń) and pre-corporation forms of settlement of early medieval traditions (Kałdus - Starogród and Stary Torun - Toruń). An attempt was undertaken to answer the question as to whether the incorporation decisions made by the Teutonic Knights a few years after arriving at the Kuyavian-Chełmno border, took into account - both in the case of Chełmno and Torun - similar socio-economic, demographic and settlement conditions; or whether we are dealing here with different models for the creation of the aforementioned urban centres. Was the basis of incorporation in both cases a prior settlement structure, or were there substantial differences between them in this regard? Therefore, the results of previous archaeological excavations conducted in Chełmno and Torun were compared, including the available written sources. Taking into account the facts concerning the origins of these centres, especially their pre-incorporation stage, it was found that more favourable development conditions occurred near today's Kałdus (pre-incorporation Chełmno). A castellany existed in Chełmno, the capital of the region, with the name recorded in written sources (Culmen). There was a well-developed settlement background too, as confirmed by discoveries of large craft and trade settlements and extensive cemeteries related to them. In contrast to Chełmno, the name of Torun was not recorded in written sources older than the time of the town's incorporation. In this area, there are no developed settlement structures, except for several points. This indicates that the town incorporated by the Teutonic Knights was founded on a so-called greenfield sites, in the vicinity of an early medieval settlement located on the Vistula River crossing (Stary Toruń), then translocated to the present site and situated at the back of a small border fortress (Postolsko - at pre-Teutonic Knights stronghold).

The common elements of the first two incorporations are political and communication conditions; both Chełmno and Toruń were located on Chełmno Land's border, at major crossings, and along overland and water long-range trade routes at the entrance to Chełmno Land from the Kuyavia and Pomerania (theory of gateway centres). Both Teutonic Knights' towns belonged to a network of centres later included to the Hanseatic League. Despite a common document, their hierarchy was strictly defined. Even in a document from 1251, the master one, the capital role of Chełmno was highlighted, which probably corresponded to the historical tradition and the special position of this centre, from which Chełmno Land took its name. 
